UDC 316.612

DOI: https://doi.org/10.21564/2075-7190.35.119643

Pogribna V. L., Doctor of Sociological Sciences, Professor;

Sakhan O. M., PhD (Sociology), Associate Professor

\title{
RESOURCES AND RISKS OF PERSONAL AUTONOMY IN THE MODERN UKRAINIAN SOCIETY: SOCIOLOGICAL ASPECTS OF THE ANALYSIS
}

The sociological aspect of the issue related to personal autonomy under the terms and conditions of the modern development of the Ukrainian society has been considered. It is proved that autonomy, as an integrative quality of an individual, is formed and manifested in the course of the social interaction of individuals in various life spheres. It is shown that the personal autonomy is determined by the freedom to choose the actions in different social situations, the possibility of own individual potential realization during selection and implementation of any activity. The reasons and social consequences of the risks of the personal autonomy in the modern Ukrainian society have been analyzed.

Keywords: personality, autonomy, mentality, social activity, political activity, independence resources, and independence risks.

Target setting. Socio-political changes that are going on in the modern Ukrainian society require people to quickly orient themselves in new circumstances, to independently self-manage their behavior and to act in accordance with their personal motivation, not controlled externally, to take decisions and to make choices that are most relevant to the circumstances that have developed. Depending on the level of the personal autonomy and various resources that a person can use to achieve his/her own goals for certain purposes, a person establishes his/ her contacts with the outside world (from the manifestation of independence to indifferent subordination) and demonstrates the ability to effectively influence not only his/her life but also the surrounding world. However, the personal autonomy can cause risks, whereas negligence thereof may lead to consequences that are difficult, and sometimes even impossible, to be rectified. In connection therewith, the issue of showing the meaning of the main resources and the possible risks of the personal autonomy in the modern Ukrainian society becomes of particular importance.

The rationale of the possibilities and obstacles to the personal autonomy formation is caused by the theoretical and practical needs of the social transformations in Ukraine. Today we should state that the relatively passive role of the participants in the social interactions, which has been observed over the last decades of the $20^{\text {th }}$ century, has been changed significantly. And this can only be explained by the 
process of building of democratic institutions of the society (all the more so as there are opposite tendencies) or the growing role of the subjective factor is clearly not enough. It is a qualitatively new phenomenon - an access to the social arena for a large number of self-acting individuals. A person becomes not only a formal agent (according to P. Shtompka) of the historical process but also gets the opportunity to influence various aspects of his/her own life in the economic, social, political, and spiritual spheres of being. His/her potential is changing substantially because it is based on the ability to effectively influence the surrounding world and himself/ herself. In this case, the researcher has a number of issues that require immediate resolution. The most important among them are as follows. Firstly, in what way is this potential formed and realized? Is it in demand in modern Ukraine? Secondly, does the increase in individual autonomy increases his/her freedom, especially when it affects the interests of those who already own property, power and other instruments of influence? Thirdly, what are the prospects and consequences of the development of the mass independence for a person and society as a whole? How is the tendency of the personal autonomy growth consistent with a need in the social partnership system development? Or is it, maybe, just an illusion of partnership, which only hides the change in the nature of social communications? Thus, the issue related to the determination of the resources and risks of the individual autonomy in the modern Ukrainian society is actualized.

The analysis of the recent studies and publications certifies the fact that certain aspects of the issue under study have already been in the scientific interest of Ukrainian and foreign scientists. The issue of the individual autonomy is most highlighted in the psycho-pedagogical studies of G. O. Ball, F. Benson, H. M. Hodina, Yu. M. Dmytrieva, M. I. Makhmutov, P. I. Podkasysty, A. H. Khrypkova (essence, nature and structure of independence, the ratio of its components); P. K. Anokhin, S. Yu. Golovin, O. H. Kovaliov, H. S. Kostiuk, O. V. Petrovsky, D. A. Tsyrinh, Z. I. Shylkunova, V. Ya. Yablonko (various properties and personal features); R. S. Bure, Z. V. Yelisyeyeva, K. P. Kuzovkova, M. V. Krulekht, A. A. Liublinska, S. A. Marutian, N. Ya. Mykhailenko, S. L. Rubinstein, V. O. Sukhomlynsky, K. D. Ushynsky (stages, conditions and methods of independence development); Z. V. Halazhynsky, E. Ya. Golant, L. H. Dyka, A. L. Zhuravliev, L. A. Korostyliev, A. B. Kupreichenko, V. I. Morosanova, H. S. Pryhin (various phenomena of the personality autonomy, among which, for example, self-regulation, self-affirmation, self-realization, etc.) and others. However, a few sociological studies of this issue (Yu. I. Giller, M. Kon, P. Shtomka) [1-3] are limited to the consideration of the phenomenon of autonomy in combination with other personal features, leaving the issue of resources and risks without due attention, that causes new scientific research. 
The purpose of the article is to identify the resources and to determine the ways to reduce the risks of personal autonomy in the modern socio-political space of Ukraine in the context of the sociological science.

Statement of basic materials. Independence (in psychology - internality) is one of the most important volitional powers of an individual that is formed in the process of his/her socialization and reaches a certain level of development during education and upbringing and individual implementation of various activities. In fact, it is the development of self-being (according to J. Mid), the disclosure of the individual's human potential. Independence is manifested in the active position of the individual in relation to the realization of the set goal, in the ability to act regardless of any external influence, to rely on own forces, views and beliefs, taking into account the position and experience of other persons, and to be responsible for their own actions and consequences thereof.

Internal qualities of a person, his/her knowledge, skills and abilities, psychological characteristics, attitude to the process of activity, results and conditions of its implementation, in conjunction with the external living conditions (socio-political, economic, spiritual and cultural, etc.) and the nature of social relations, which are caused by the historical types of the relationship between a person and the social space, determine the degree of autonomy and resource potential of the individual.

During satisfaction of the needs, implementation of the interests and values of the individual there may be the risks of its independence. This, among other things, relates to the level of freedom and socio-legal protection of human rights in a concrete historical social system, the dependence of psychological characteristics of a person on the parameters of the socio-stratified and socio-class structure of society and the ability to use its resources (economic, material, human, social, organizational, political, moral, spiritual, cultural, informational, etc.) to support their actions and activities when achieving the goals.

Long-term being of the Ukrainian population under the terms and conditions of permanent opposition of political forces, high level of corruption and selective justice, unemployment, depreciation of the monetary unit, rapid change in the priorities of life, as well as violent events of recent years (Revolution of Dignity 2013-2014, Russian armed aggression against Ukraine, annexation of the Crimea, etc.) contributed to the fact that the paternalistic mood of the Ukrainian society began to yield to an active civic position. Thus, the level of independence in the consciousness and actions of Ukrainians has started to increase actively.

The rethinking of the today realities by the citizens of our country, the understanding of the essence of the processes taking place in the society, the desire to have confidence in the future and the real protection of their rights and freedoms, 
the desire to accelerate the implementation of the European standards in all spheres of public life have encouraged a significant part of the Ukrainian society to have a sense of responsibility for their country, readiness to take an active part in democratic transformations, the process of the state reformation and the development of civil society institutions, protection those interests of fellow citizens, attempts to find their own ways to take part in the social and political life and relations with the authorities.

On the socio-political arena there were subjects of new types - born and upbrought under the terms and conditions of an independent Ukrainian state that are not burdened with authoritarian and conservative views, are confident in their forces, whose activity determines the directions of development of all spheres of the public life [4, p. 152]. People's awareness of the community of their interests with the interests of those social and political groups to which they belong due to objective and subjective factors, a civil status of the subject, endowed with rights, freedoms, and opportunities to influence the power formed the motivation of the active inclusion of a person in the political sphere of life of the modern Ukrainian society, manifestation of autonomy and initiative of the individual. The revival of the values of freedom, dignity, and patriotism, liberation of creative potential and civic activity in the socio-political space of Ukraine contributed to the fact that people had a belief "in their own ability to assume the responsibility for their actions, as well as the fact that the society has a form of government that enables the expression of independence" [5, p. 56].

Today you can state that democracy has become an essential feature of the modern Ukrainian mentality and a condition for the self-realization of separate individuals and social groups. People have started to sympathize more and help each other, to overcome indifference, and to direct their efforts in support of the front, restoration of the Ukrainian army, and formation of new institutions of the civil society [6, p. 360].

Sociologists have put the following question in the questionnaire throughout the years: "Are you proud of your country?" That said, most respondents did not usually conceal their skepticism: what to be proud of - worldview amorphous, traditional "it is no business of mine"? Now everything has changed. Nowadays there is an increase in the dignity of the people, a focus on self-realization and autonomy, which increases self-assurance of Ukrainians, helps to find support due to the traditional and new values and internal unity with other people. According to Anatoliy Ruchka, the chief researcher of the Institute of Sociology of the National Academy of Sciences of Ukraine, the phenomenon of creative individualism is connected with the positive self-realization and independence. He considers the creative individualism as a citizen's responsibility for himself/herself, his/her fam- 
ily, his/her own life-making, and awareness of the value of his/her personality. Uniting in extreme conditions, Ukrainians demonstrate creative self-realization, defending the public interests of everyone in their place, forming a civil society from a number of civil initiatives. Accordingly, the level of solidarity of the society increases [7]. This means that during the extraordinary events, the mentality of our citizens is subject to a certain value metamorphosis, connected, first of all, with the marked increase in the importance of not only patriotism and democracy, but also creative individualism and cultural competence, which form the basis of the personal mental autonomy [8].

Mental autonomy is an indicator of the level of human claims and assessment of the degree of his/her individual control over the characteristics of life-sustaining activity, relative autonomy and impact on the surrounding world. If we consider the mechanism of behavior regulation either as a hierarchical or as a coordinated dispositional system, this characteristic is not just the dominant value orientation of a person, but the "prism», which integrates the integrity in the consciousness of society. This prism determines for a person his/her social status and role in the society, as well as his/her attitude towards himself/herself. One can agree with Yu. Giller that «... mental autonomy forms the direction of activity for a person and the degree of freedom in his/her choice determines where (within or outside the person) the dominant source of this activity is. Thus, the consent of the active participants of social relations to the established interaction provides for their consent to the limits of their activity (freedom) and the sources that determine these limits. This agreement forms the basis for the general meaning of the social interaction» $[1$, p. 88$]$.

It should be noted that the content of the very mental characteristics of both independent and non-independent personality regulates his/her behavior in specific situations. The analysis of the specifics of communal (Gemeinschaft) public (Gesellschaft) relations, conducted by F. Tionsis, is very illustrative here [9]. In a traditional society based on community relations, the main social regulator of relations between people is the traditional social norms, which in consciousness are reflected in the form of uncritical behavioral arrangement - the absolute willingness to adhere to these norms in their own behavior with the minimal independence of choice. In the modern society, where social relations dominate, compliance with the rules and regulations is almost always associated with the process of the internal choice, which is ensured by the presence of a certain rational justification of the corresponding decision, that is, a high degree of the personal autonomy.

Based on the mental characteristics, direction and nature of manifestations of activity in the society, an internal attitude of a person to the principles of social interaction and its subjective assessment are formed. This thesis, in our opinion, is extremely important for the analysis of the resources of an independent person, as 
a mental resource, of course, serves as a source of the personal autonomy formation and development, because it activates social reserves for solving the strategic tasks of the society.

Under the terms and conditions of differentiation of social status, the issue of subjective attitude to social inequality and social domination is directly related to the problem of social justice. The basis for assessing the social domination as fair or unfair is the character of the mentality of the interacting people and, above all, their perceptions of the origin of the system of social relations that have developed and the possibilities for its change. Z. Baumann, referring to the research of B. Moore Jr., states: «... in only a few cases, the suffering that fell on the people's share was perceived as unfair and caused protests. Usually, only "excessive" suffering, that is, more severe than those that have been experienced in the past, are perceived as "unfair» [10, p. 36]. This means that the habit, the tradition of the rules, regulating the relations in certain social situations, the lack of variability in their implementation, do not put into doubt the justice of the members of the society. Accordingly, attitudes, formed on this basis, have the nature of uncritical automatic behavioral readiness of a person to perform them, that is, they produce inertness of the personality. An independent person acts in a different way: «The practice of people's coming to Euromaidan has shown that the energy of self-organization of Ukrainian citizens has a great potential for consolidation around socially significant problems» $[11$, p. 8$]$, and, therefore, mobilizes the external resource of the autonomy.

In addition to the external resource - mental - you can determine the number of internal resources, which can be used by a person to consciously influence the situation, namely:

- psychophysiological (physical strength, psychological qualities);

- intellectual (abilities, type of thinking);

- acquired during education and various social practices (knowledge, abilities, and skills).

Behavior that does not rely on these resources is passive and is usually ineffective. As K. Abulkhanova states, characterizing the social behavior of a person, «no deep knowledge of motivation and will, cannot help the psychologist to understand the reasons for weakness and passivity, if he/she does not take into account the pessimistic attitude of the individual to life» [12, p. 43]. And then: «The subject of activity is a synthesis of personal features and ways of being engaged in the activities and requirements of activity to an individual. This synthesis is executed in the form of tasks in which the subject can transform not only its own personal and psychological resources, but also the conditions and requirements to activities themselves» $[12$, p. 45]. Thus, we can assume that the level of the personal autonomy is the degree of implementation of his/her subject potential. 
The conditions that ensure a possibility of the individual autonomy development is his/her relative independence, that is, freedom from absolute subjugation to the situation, and the availability of the resource potential of the situation.

Relative independence of an individual is determined by the freedom to choose actions in different social situations, and, therefore, a person's possibility of his/ her individual potential realization during selection and implementation of the activities. Resource potential of the situation indicates his/her ability to provide a person with the material, social, political, cultural resources, which enable the person to actively influence the social processes in the society. At the same time, the importance of social resources and resource use (according to P. Bourdieu) should be emphasized - as a recognition of the special importance of those attributes of subjects (actors, agents) in the society that allow them to establish their "rules of the game" in the system of social relations.

The analysis of the basic levels of human autonomy, conducted by Russian sociologist $\mathrm{Yu}$. Giller, is quite interesting in this sense. He allocates three such levels. The researcher relates the first level to situations where human attempts to carry out independent activities can cause life risks, and the stability of social relations is based on unconditional conscious or unconscious readiness of people to exchange the possible freedom for life. It is a biological autonomy.

The second level of autonomy, according to Yu. Giller, no longer correlates with direct threats to life, but is produced by situations of social coercion, when the stability of social relations is based on the readiness of people to deliberately exchange the freedom of choice of the type of desired activity to satisfy a set of standard needs. This is the autonomy of guaranteed life-sustaining activity (satisfaction of all standard needs of stable operation).

The Russian sociologist presents the third level of autonomy of the personality as that one providing for consideration of the requirements of the regulation, that is, compliance with certain characteristics of its chosen activities is limited only by a need to reconcile own interests with the interests of other social actors. The stability of social relations, in this case, is based on the readiness of a person to meet the regulation requirements. This is autonomy of self-realization of a person. It is the third level of autonomy, of course, that he considers as the basis for the formation of an independent person [1, p. 45-48].

However, the last thesis of $\mathrm{Yu}$. Giller raises quite reasonable questions - if the autonomy entitles a person to act at his/her own discretion, does that mean that it is possible to fail to fulfill any requirements or to refrain from active efforts at all? Moreover, can such a manifestation of autonomy be considered as the foundation of individuality? And finally, if so, what are the social consequences of an individual's identity? We believe that the answers to these questions center on the 
analysis of the phenomenon of individual self-identity through the prism of the risks that it creates.

As we know, the development of human activity, first of all, is aimed at maximizing own self-realization. However, the nature of this desire is largely determined by the characteristics of the culture of the society in which a person is. At the same time, the desirable self-realization is manifested, in general, not in the fact that the person realizes himself/herself in the same degree in the entire set of social relations, in all spheres of activity, but in the fact that the dominant activity captures a person as a whole. How does the «plunge» of a person into a dominant activity take place? Z. Bauman believes that in the modern society, under the terms and conditions of the pressure of mass culture imposed by the mass media, this activity is not the result of an independent choice of a person, but manifests itself in the choice of one of the socially representative forms proposed for a person by standard examples of the culture of the society [10, p. 108-109]. Therefore, guided by the characteristics of the culture of the society and the related mentality, value orientations and attitudes, as well as the level of its own activity, a person in pursuance of self-realization and independence will not always try to change the social "for him/ her". As it can be determined there are several reasons for the latter (personal unwillingness to actively protest actions, a lack of resources for this, the nature of personal qualities, etc.), but a special role plays the reason that demonstrates the connection between the individual's individuality and the social risks that follow there from.

The risk for an active self-employed individual is associated by most people not only with the process of struggle for changing the situation in the society but also with the possible negative consequences of such a change for the person himself/herself. First of all, it is a fear of raising the level of responsibility for their own actions, when a person begins to realize himself/herself as an active social actor. Such fears lead to the emergence and spread of such a specific phenomenon in the society as a strategy of adaptive activity (according to Yu. Hiller). In this strategy, the risks of autonomy are valued by humans higher than the preferences that result from its development, and, accordingly, restrict autonomy.

The social counterweight for this strategy is a strategy based on the assurance of the individual and social significance of self-sufficiency and the corresponding social activity, intolerance to the adaptive position. In the postmodern society, this behavior is formed as a reaction to the attempts of the state to appropriate the most influential role in the life of the society, the desire to put the burden of the society on the shoulders of citizens without providing any resources, necessary for their solution, the ever-increasing volatility and dis-functionality of a large number of social institutions, including political ones. But at the same time, there is a risk of 
inhibition of the rational component of the social activity, the emergence of irrational aggression as a reaction to its own powerlessness. Under such conditions, the role of random factors of an impact on human behavior increases, which, in accordance with the effect of synergy, increases the risks of individual autonomy. However, we do not see the meaning of exaggerating the significance of these factors for the independence of the individual, because they affect the choice of the strategy of activity rather than the lack/availability of the autonomy.

There is another risk of personal autonomy, which we propose to define as a «risk of social memory». This risk is of particular importance in transitional or mobilized (by Yu. Levada), societies, and hence, in Ukraine. Up to date, a significant number of Ukrainians feel phantom belonging to the former USSR, and «Soviet» continues to affect their social well-being and behavior. These are mainly elder and elderly people, among whom there are many representatives of all branches of the state power, all of whom used to live under the conditions of a totalitarian political regime, who categorically dislike the socio-political changes taking place in the country, seek to preserve the already established ones, habitual and understandable for having a vague hope for "objective" positive changes in the future, while waiting for the authorities to solve their own problems. Due to the nostalgia for the past, they do not feel like a representative of the new community the Ukrainian people that leads to the increase in the mental confrontation of citizens and to the postponement of consolidation processes in the Ukrainian society. Playing the role of passive, apolitical or indifferent to politics individuals who, at best, in a neutral way, and at worst, disrespect power and politics, these citizens stand in the way of any democratic change in the society, inhibiting the processes of stimulating the responsibility of politicians and exposing the most active participants in the political process to risk (for example, the loss of public loyalty to their methods of work and the constant overcoming of the situation of general unpreparedness of the population to modernize the society, instead of the focus on solving the pressing issues of social importance, etc.).

A testing ground for individual autonomy is its involvement in the political life of the society. Depending on the political status of the subject in the political system and its role in the political process, the level of individual autonomy and the amount of resources that it can use to influence the authorities and the course of political events, achievement of the socially meaningful goals through the external (behavioral) level of political activity, shall be determined. Under the today's conditions of democratization of the society and modernization of power, the integration of Ukraine into the European space, independence of the individual manifests through a wide range of political activity, which is realized in various forms of political behavior, political participation and political activity. 
Among the resources, used by a person to take part in the political sphere of the society, there are «resources of a citizen (knowledge, time, money) and socialization of a person through participation in the structures of the civil society» $[13$, p. 27]. Its education and profession, political knowledge, values and ideals, the level of political culture, competence, self-confidence, positive mood, authority, teamwork, willingness to cooperate, tolerance, responsibility, ability to meet a challenge, emotional stability, readiness for change, etc. are important for the fulfillment of the functions relevant to the political status of the subject. If these qualities of an individual are not developed or filled with conflict-related or even destructive content, there may be risks of his/her independence. This happened with N. Savchenko, who, on a huge loan of trust and support on the part of the society and government, has become a big politician (she became a deputy of the Verkhovna Rada and a PACE delegate), but very quickly lost her credibility and all allies due to inexperience, political incompetence, low level culture, including political, irresponsibility and self-confidence. A number of inadequate statements and ridiculous actions, performed by N. Savchenko as a deputy of the Ukrainian parliament, which disoriented the international community, have led to discrediting this person as a national heroine and to the devaluation of her image.

Political rights and freedoms that allow a citizen to influence the political life of the country are provided with legal resources of the state: state-legal institutes, rules and procedures that form the basis for a legal democratic state. The personal autonomy in the political sphere of the society's life is based on the trust and support of «strong communities", capable of solving complex problems based on a common vision, a sense of belonging and a positive attitude, recognition of the value of diversity and the development of networks of interaction» [12, p. 21], which together with the new political institutions and procedures and civil society form the structural resources of the society.

The personal autonomy has been manifested in the voluntary activity of the community, aimed at helping people in a unique volunteer movement, institutional units of civil society, which is a selfless (in most cases anonymous), which have arisen as a response to the call of the society for assistance in the development of the events of 2013-2014. The most active citizens formed a network of voluntary associations and organizations for solving the strategic issues for the development of the Ukrainian society, proving the ability of Ukrainians to self-organize and to oblige different political forces to reckon with public opinion. This structural resource of the society has become not only a significant element of the civil society, but also revealed the best qualities of the individual, based on which people can avoid the risks of independence, namely: knowledge, competence and professionalism, purposefulness, responsibility and self-discipline, humanity, justice, tolerance 
and openness, decency and honesty; high level of culture, optimism, confidence in their abilities in achieving their goals and other qualities that meet the challenges of the present.

Conclusions. Autonomy is a complex, integral quality, a feature of the character of a person, which is formed during socialization and is manifested in various spheres of activity. The right of an individual to self-realization implies his/her responsibility to the society, the resources thereof he/she enjoys to implement the plans. In the modern post-Soviet countries, a tendency which characterizes the desire to minimize the risks associated with possible constraints in satisfying the standard set of needs has been established, that is, people are not ready to sacrifice the quality of their own lives for the sake of achieving a vital life success, but are ready to actively work for the purpose of the growth of their human capital [14, p. 133-134]. Thus, the prospects for the development of an independent personality in Ukraine are in the direction of holistic self-realization, which is based on the increase of individual human capital. It is in this way that a person acquires the opportunity to actively realize his/her individual and social potential. Therefore, special emphasis should be put on the development of the individual autonomy from childhood through all the institutions of his/her socialization (family, educational, cultural and artistic and sports institutions, mass media, army, church, etc.).

The transformation of the potential opportunity of the personal autonomy in Ukraine from an individual phenomenon into the mass one will not happen "automatically". This requires counter-measures of the society and citizens and the awareness of the fact that any significant transformation in the society creates both opportunities and significant threats (risks) for the society and its citizens. The concrete trajectory of the social development is increasingly determined by independent individuals who are clearly aware of these opportunities and risks and can respond to them adequately.

\section{REFERENCES}

1. Giller, Yu.I. (2006). Sotsiologiya samostoyatelnoy lichnosti: monografiya. Moskva: Akademicheskiy Proekt; Gaudeamus [in Russian].

2. Kon, M. L. (2013). Sotsialni strukturi i osobistist: doslidzhennya Melvina L. Kona i yogo spivpratsivnikiv / per. s angl. pid nauk. red. V. E. Hmelka I S. M. Oksamitnoyi. Kiyiv: KMIS [in Ukrainian].

3. Shtompka, P. (1996). Sotsiologiya sotsialnyih izmeneniy / Per. s angl. pod red. V. A. Yadova. Moskva: Aspekt Press [in Russian].

4. Markozova, O. O. (2013). Samostiynist lyudini yak osnovna peredumova dosyagnennya zhittevogo uspIhu. Visnik Natsionalnogo universitetu «Yuridichna akademiya Ukrayini imeni Yaroslava Mudrogo». Seriya: Filosoflya, filosofiya prava, politologiya, sotsiologiya, 4, 152-159 [in Ukrainian]. 
5. Dieva, T. S. (2005). Vzaemozv'yazok sotsialno-stratifikatsiynoyi pozitsiyi ta samostiynosti orientatsiy na pochatku radikalnih sotsialnih zmin v Ukrayini. Naukovi zapiski NaUKMA, Sotsiologichni nauki, 46, 56-59 [in Ukrainian].

6. Sahan, O. M. (2017). Mentalnist ukrayinskogo sotsiumu v umovah transformatsiynih protsesiv v suspilstvi. Visnik Natsionalnogo universitetu «Yuridichna akademiya Ukrayini imeni Yaroslava Mudrogo». Seriya Politologiya, 2, 358-361 [in Ukrainian].

7. Kirichenko, I. Triumf «voyiniv svitla»: pidvischennya gradusa intelektu i pochuttiv. URL: http://gazeta.dt.ua/socium/triumf-voyiniv-svitla-pidvischennya-gradusa-intelektu-i-pochuttiv-.html [in Ukrainian].

8. Pogribna, V. L. (2016). Volonterskiy ruh yak oznaka zmin u mentalnosti ukrayintsiv. Visnik Natsionalnogo universitetu «Yuridichna akademiya Ukrayini imeni Yaroslava Mudrogo». Seriya: Filosofiya, 1, 196-203 [in Ukrainian].

9. Tennis, F. Obschnost i obschestvo. URL:http://socioline.ru/pages/f-tennis-obshchnosti-obshchestvo [in Russian].

10. Bauman, Z. (2005). Individualizirovannoe obschestvo / Per. s angl. pod red. V. L. Inozemtseva. Moskva: Logos [in Russian].

11. Pro stan rozvitku gromadyanskogo suspilstva v UkrayinI: zagalni tendentsiyi, regionalni osoblivosti: analit. dop. (2014). Kiyiv: NISD [in Ukrainian].

12. Psihologiya individualnogo i gruppovogo sub'ekta / pod red. A. V. Brushlinskogo, M. I. Volovikovoy (2002). Moskva: PER SE [in Russian].

13. Kavilin, O. A. (2016). Institutsionalizatsiya politichnoyi uchasti molodi v suchasniy Ukrayini. Candidate's thesis. Ivano-Frankivsk [in Ukrainian].

14. Magun, V., Engovatov, M. (2003). Ambitsii i amunitsiya rossiyskoy i ukrainskoy molodezhi. Moskva: Demoskop Weekly [in Russian].

\title{
РЕСУРСЫ И РИСКИ САМОСТОЯТЕЛЬНОСТИ ЛИЧНОСТИ В СОВРЕМЕННОМ УКРАИНСКОМ ОБЩЕСТВЕ: СОЦИОЛОГИЧЕСКИЕ АСПЕКТЫ АНАЛИЗА
}

\author{
Погребная В. Л., Сахань Е. Н.
}

В статье анализируются социологические аспекты процесса становления и реализации самостоятельности личности в современных украинских реалиях. Доказано, что самостоятельность, как интегративная характеристика личности, формируется и проявляется в ходе сочиального взаимодействия индивидов в различных сферах жизнедеятельности и определяется свободой выбора действий в различных социальных ситуациях, возможностью реализации в процессе выбора и осуществления деятельности собственного индивидуального потенциала. Проанализированы виды, причины и социальные последствия рисков самостоятельности личности в современном украинском обществе. 
Ключевые слова: личность, самостоятельность, ментальность, социальная активность, политическая активность, ресурсы самостоятельности, риски самостоятельности.

\title{
РЕСУРСИ ТА РИЗИКИ САМОСТІЙНОСТІ ОСОБИСТОСТІ В СУЧАСНОМУ УКРАЇНСЬКОМУ СУСПІЛЬСТВІ: СОЦІОЛОГІЧНІ АСПЕКТИ АНАЛІЗУ
}

\author{
Погрібна В. Л., Сахань О. М.
}

У статті аналізується якісно нове явище - вихід на соціальну арену великої кількості самостійно діючих особистостей. Людина стає не просто формальним агентом історичного процесу, а отримує можливість впливати на різні аспекти власної життєдіяльності.

Доводиться, щуо переосмислення украӥниями реалій сьогодення, розуміння сутності прочесів, щуо відбуваються в суспільстві, бажання мати впевненість у завтрашньому дні та реальний захист своїх прав і свобод, прагнення пришвидиити впровадження європейських стандартів у всіх сферах суспільного життя сформували у значної частини украӥнського сочіуму почуття відповідальності за свою країну, готовність взяти активну участь у демократичних перетвореннях, прочесі реформування держави та розвитку інститутів громадянського суспільства, захисті інтересів співгромадян, намагання знайти власні способи участі у суспільнополітичному житті та взаємовідносин із владою.

Авторами зазначається, щзо ментальна самостійність в умовах сучасної України стає основним зовнішнім ресурсом та індикатором рівня домагань людини і оцінки ступеня ї̈ індивідуального контролю характеристик життєдіяльності, відносної автономності й впливу на оточуючий світ. На основі характеристики внутрішніх ресурсів особистості - психофізіологічних, інтелектуальних та набутих в проиесі навчання і різних сочіальних практик знань, вмінь і навичок-доводиться, щзо поведінка, яка не спирається на изі ресурси, є пасивною та зазвичай малоефективною, а умовами, щзо забезпечують можливість розвитку самостійності особистості, є ї̈ відносна незалежність та наявність ресурсного потенціалу ситуації.

Досліджуючи ризики самостійності особистості в сучасній Украӥні, автори підкреслюють, шуо у більшості людей вони асоиіюються з можливими негативними наслідками для них соціальних змін, щуо відбуваються. У першу чергу, цуе побоювання підвищення рівня відповідальності за власні діï, які призводять до виникнення та поширення в суспільстві такого специфічного явища, як стратегія пристосовувальної активності. У изій стратегї ризики самостійності оцінюються людьми вище, ніж преференції, щзо отримуються внаслідок ї̈ розвитку, $і$, відповідно, обмежують самостійність. Ще один ризик самостійності особистості визначається, як «ризик сочіальної пам'яті», пов'язаний з тим, щзо значна кількість україниів досі відчуває фантомну належність до СРСР, $і$ «радянськість» продо- 
вжує впливати на їх сочіальне самопочуття та поведінку. Проведений аналіз дозволяс авторам дійти висновку, що перспективи розвитку самостійної особистості в Украӥні містяться в напрямі иілісної самореалізаиії, і саме в такий спосіб люди набувають можливості активно реалізувати свій індивідуальний та соиіальний потенціал.

Ключові слова: особистість, самостійність, ментальність, соціальна активність, політична активність, ресурси самостійності, ризики самостійності.

\section{$\operatorname{son}$}

